\title{
Conservation of Damar Mata Kucing (Shorea javanica): A Review on the Aspect of Trade System
}

\author{
Hanifah Nur'aini ${ }^{1}$, Ervizal A. M. Zuhud ${ }^{2 *}$, Tutut Sunarminto ${ }^{2}$ \\ ${ }^{1}$ Graduate Program of Tropical Biodiversity Conservation, Faculty of Forestry and Environment, IPB University, Academic \\ Ring Road, Campus IPB Dramaga, Bogor, Indonesia 16680 \\ ${ }^{2}$ Department of Forest Resource Conservation and Ecotourism, Faculty of Forestry and Environment, IPB University, \\ Academic Ring Road, Campus IPB Dramaga, Bogor, Indonesia 16680
}

Received March 10, 2020/Accepted November 30, 2020

\begin{abstract}
Damar mata kucing (Shorea javanica) is one of the non-timber forest products (NTFP)s that has been widely managed and utilized by local people around the Pesisir Barat Lampung Province. The majority of repong damar has been cut down, especially during the last 15 years. One of the reasons for decreasing community interest in managing repong dammar is the decreasing of dammar gum prices. This research aimed to analyze the market system of dammar cultivation in Pesisir Barat, Lampung Province. Descriptive analysis was used to determine the local community's knowledge, skill, and opinion in the trading channel. For further analysis, marketing margin and farmers' share were also used to analyze the price differentiation from the producer's level to the consumer's level. Based on the study results, there are three channels of the dammar gum market in Pesisir Barat Lampung. Most of the farmers (up to $85.71 \%$ of total) in Pekon Pahmungan use trading channels 1 and 2 to sell their harvested dammar. Meanwhile, based on the analysis of profit margin, it appears that farmers in channels 1 and 2 are trading actors that receive the lowest profit margin (IDR7,100 kg-1 and IDR8,100 $\mathrm{kg}^{-1}$ ) compared to trading channel 3 (IDR 14,000 kg-1). Farmer's share obtained by dammar farmers in this study was $55.30 \%$ on channel 1, 52.20\% on channel 2, and $76.80 \%$ on channel 3. Livelihood, limitation on capital, lack of information and networking, knowledge and abilities to tree management and harvested dammar, knowledge of another use of dammar gum, and the ability to use technology directly affecting farmers' position in the dammar gum trading system.
\end{abstract}

Keywords: damar mata kucing, NTFPs, sustainability, institutions, community

*Correspondenceauthor,email:eamzuhud@apps.ipb.ac.id

\section{Introduction}

Dammar (Shorea javanica) is one of the non-timber forest products (NTFPs) that has been widely managed and utilized by local people. They lived over a generation at the border of the rainforest in South Sumatera, especially in the Pesisir Barat, Lampung Province (Mary \& Michon, 1987; Anasis \& Sari, 2015; Gilbert, 2017). Forest management practices invented and developed by local people have proven to be efficient in fulfilling basic household needs and being able to guarantee the sustainable use of natural resources for more than a century (Murniati et al., 2001; Kusters et al., 2007). From the conservation of the forest resources point of view, the agroforest system maintains a high level of biodiversity and the forests' ecological functions (Michon et al., 1987). The agroforest system structure provides sustainability for long-term productivity through maintaining soil and water quality while providing other environmental benefits such as carbon sequestration and preserving the diversity of both forest plants and invertebrate and vertebrate animals (Nyhus \& Tilson, 2004; Mutuo et al., 2005). While implemented in buffer zones, the agroforestry system is expected to help protect the remaining natural forests (Nyhus \& Tilson, 2004). From an economic perspective, the agroforestry system provides a wide range of income sources to rural and urban households and the actors along the dammar gum trading chain (Bouamrane, 1996).

Anasis and Sari (2015), in their research, stated repong damar in Pesisir Barat Province suffered from the degradation of land area that would threaten the sustainability of dammar plants. In some areas, repong damar has been greatly reduced. Over the past few years, many people have sold their land or converted to seasonal plantations (Gilbert, 2017). According to Gilbert (2017), most repong damar in Pesisir Barat have been cut down, especially during the last 15 years. One of the main reasons is the low and decreasing dammar gum prices (Wollenberg et al., 2001; Gilbert 2017). From the aspect of a sustainability point of view, this condition will threaten dammar gum producing plants because it will spur the community/farmers to switch to commodities that are more economically promising. 
Conservation is a management effort carried out by humans in utilizing natural resources to guarantee sustainable community development while still maintaining its potential to meet human needs in the future. Efforts to conserve forest resources will not be effective without the sustainability approach used by the local community. Sometimes, people are reluctant to conserve a type of plant due to a lack of information about the plant. But many people are unwilling to conserve a plant species because it is not economically beneficial. Fischer (2010) stated that sufficiently high resource prices could facilitate good management regimes and trade gains. Relative prices can also influence the value of other production factors, including the opportunity cost of land when land can either serve as habitat for the other resources or be converted for other uses, like agricultural cultivation. Higher resource prices can increase the value of maintaining habitat and expanding the resource base (Barbier \& Schulz, 1997).

The market price of certain resources is influenced by its trading system (the farmers, the traders, and the interaction between actors in the market). The low level of price of forestry commodities at the farming community level can be caused by various factors: low quality of harvested products, lack of knowledge of the local people, and long supply chains (Menggala, 2018). To understand how a market price is derived, it is important to understand some basic trading concepts. This study's objectives are: 1) to identify the characteristics of dammar gum farmers that affect the position of farmers in the trading system, 2) to identify dammar gum trading channels in Pesisir Barat Lampung, and 3) to analyze trade margins, and farmers share as indicators of trading efficiency.

\section{Methods}

This research was conducted in August-September, 2019 in Pekon (village) Pahmungan, Pesisir Barat District, Lampung Province. The selection of research locations was conducted purposively. The main reason is that the site produces a large amount of dammar gum in West Sumatera, and there is still quite a lot of repong damar and people working on it. For the study purpose, both primary and secondary data are used. Primary data were gathered through field observation and interviews. Respondents consist of smallholder farmers who produce and sell dammar gum (who is directly involved in the management of repong damar), government officials related to forest resources management, local leaders in dammar business, and other trading agents involved in the channel. A purposive sampling approach was used to select respondents. This is the most common method researchers use in nonprobabilistic sampling (Guest et al., 2006). In total, 50 respondents comprised of 35 collectors, 10 middle-men, 5 big sellers, were interviewed.

Descriptive analysis was used to describe the trading channels, agents involved in the dammar gum trading, and the functions performed by each agent. The quantitative analysis was used to study or analyze a dammar gum trading system's efficiency by looking at the trading margins and farmers' share.

Data were collected through a questionnaire, then processed and categorized into three categories: high, moderate, and low. Categorization the level of knowledge of respondents using parameters: 1) high, if the value of the respondent $(\mathrm{x})>$ mean $+1 \mathrm{SD}$; 2) moderate, if the respondent's mean is $-1 \mathrm{SD}<\mathrm{x}<$ mean $+1 \mathrm{SD}$; and 3) low, if the respondent's value (x) $<$ mean - $1 \mathrm{SD}$ (Azwar, 2012).

\section{Results and Discussion}

External factors Devaux et al. (2016) identified factors that influence farmers in the trading system; the presence of community groups/organizations, support from external agents (government, NGOs, or research organizations), counseling, relationships with marketing actors, and access to financial resources. The results showed that a strong external factors were not formed in the series of dammar gum trading activities, especially in Pekon Pahmungan.

There are no farmer groups/organizations formed in Pekon Pahmungan when the data is conducted. Lack of agroforestry development can be caused by the low role of farmers' groups/organizations (Ruhimat, 2017). Therefore, developing and increasing the institutional capacity of farmer groups are expected to optimize the development of agroforestry. Based on the interview, there are no counseling and assistance from the government, NGOs, and universities related to agroforestry and dammar business improvements. Ongoing service from all parties, especially the local government, is expected to improve dammar business and increase farmers' income to develop dammar gum as an agroforest commodity sustainably. Assistance and support from the government and other parties aim to provide protection and empower farmers and farmers' groups. The government's assistance is needed to support farmers by guarantee the availability of production facilities and infrastructure and guarantees for the marketing of the product (Kuswardani et al., 2017).

Characteristics of farmers in the dammar gum trading system Based on the ownership rights regime, repong damar in Pesisir Barat Lampung is a private property with the status of other use areas (APL) (Bromley, 1992). Repong damar in Pekon Pahmungan is categorized as a private land property that has been cultivated for generations by the community. Repong damar, as private property, causes the local communities to have absolute rights to their land and is autonomous in making decisions. Zuhud (2007) stated that unclear ownership rights greatly affect people's willingness to sacrifice for conservation action. Yustika (2008) also stated that clarity/certainty of ownership rights is the most important thing to be emphasized. Each owner has an incentive to use and protect their ownership rights. The status of land ownership as private property, aside from preserving repong damar, also has the potential to be a causing factor of repong damar reduction in Krui. As already happened in some areas of Pesisir Barat of Lampung. The majority of the dammar agroforests had been cleared, notably over the last 15 years (Gilbert et al., 2017). Approximately one-fifth $(\sim 12,500$ ha) of the 76,000 ha of dammar agroforests existing in 1997 were cleared by 2014 (Gilbert et al., 2017). One of the reasons people are reluctant to maintain repong damar is due to the low price of dammar gum (Triyono, 2000).

A study conducted by Karyono et al. (1996) illustrates that long dammar trading channels affect the selling price at the farmers' level. The dammar trading system, which is very 
unfavorable to farmers may threaten the sustainability of repong damar.

These trading factors can potentially threaten the existence of dammar tree (S. javanica) and repong damar system. BPS data for 2018 shows that from 15 districts in Lampung, Pesisir Barat has a fairly large percentage of poor households (14.48\%). The villages that are directly adjacent to the TNBBS area are the concentration of poverty and are generally poor villages (BPS Kabupaten Lampung Barat, 2018). Meanwhile farmers also have to deal with the rising costs of daily necessities of life amidst with a very rapid growing economy rate. Rising food prices and other basic necessities can have a devastating effect of poor households, particularly those living in low-income communities, by making it more difficult for them to afford basic food baskets (Mkhawani et al., 2015). Yet now, when forest-farmers find their dammar gum harvest does not provide a sufficient return, they can readily earn income from logging or replace dammar trees with annual crops such as coffee, cloves, pepper, and (mostly) palm oil (Gilbert, 2017). It needs many stakeholders' serious efforts to make the community continue to preserve repong damar, which has been around for hundreds of years.

Based on the study results, some factors that affect the dammar gum trading system are presented in Table 1. In the aspects of knowledge about the post-harvest process, access to market information, capital ownership, and networking, the farming community tends to have low knowledge. Meanwhile, the community recognizes the natural characteristics of damar mata kucing tree quite well.

Low community knowledge on the aspects of utilization, usage, and post-harvest process of dammar gum, less access to market information, and inadequate capitalization generally caused farmers to have a low bargaining position in trading channels. Puspitasari (2015), Abbas and Suhaeti (2016), and Courtois and Subervie (2018) state that one of the problems which farmers often face is that farmers still have a weak bargaining position in negotiating the selling price of their crops. The weak bargaining position of farmers is due to the characteristics of small farmers, including a) low quality and quantity of products, b) lack of information about current market prices, c) limited commercial skills, d) poor quality of inputs, e) market insecurity to produce, f) limited access to counseling agents, and g) the limited interest, knowledge, and access of farmers about post-harvest technology. This is reflected in the cultivation of dammar by the community in Pekon Pahmungan, where the community has low access to post-harvest technology, and low-level knowledge of the utilization and uses of dammar, and also low access to the market information and networking. When information and skill are limited or costly, agents cannot engage in optimal arbitrage (Jensen, 2007).

Dependency relationship Pesisir Barat is the main producer of damar mata kucing in Indonesia. Up to $80 \%$ of the total national damar mata kucing production comes from Pesisir Barat Lampung. Therefore, domestic factories and exporters companies that use dammar gum as a production material are very dependent on dammar gum production in Pesisir Barat Lampung. This indeed led to a relationship between farmers and traders. Traders need the local community as owners of dammar gum to fulfill the demand, while the community needs traders to sell their dammar gum. The existence of a dependency relationship led to the traditional dammar gum management system, which is informal, with no administration and no written rules or agreements (Kartikawati, 2014). When the buyer and seller have equal dependence, the relationship is balanced; when dependence on each other is unequal, the relationship is unbalanced (Blenkhorn \& MacKenzie, 1996). Anderson and Weitz (1989) also stated that when dependence is unbalanced, one party stands to gain at the other's expense.

One of dammar farmers' problems/concerns is about the unequal distribution of power in the commodity chain between farmers and traders. Dammar farmers are often believed to be particularly disadvantaged in these power relations. An imbalance in ownership of economic resources between farmers and collectors/traders characterized by an imbalance of capital, knowledge related to the use of dammar gum, access to sell crops, access to market

Table 1 Knowledge level of respondents

\begin{tabular}{|c|c|c|c|c|c|c|c|}
\hline \multirow{3}{*}{ Variables } & \multicolumn{7}{|c|}{ Categories } \\
\hline & \multicolumn{2}{|c|}{ Low } & \multicolumn{2}{|c|}{ Moderate } & \multicolumn{2}{|c|}{ High } & \multirow{2}{*}{ Total $(\%)$} \\
\hline & $\mathrm{F}$ & $\%$ & $\mathrm{~F}$ & $\%$ & $\mathrm{~F}$ & $\%$ & \\
\hline Plant bioecology & 0 & 0 & 17 & 48.6 & 18 & 51.4 & 100 \\
\hline The use of dammar gum & 17 & 48.6 & 18 & 51.4 & 0 & 0 & 100 \\
\hline Dammar cultivation & 0 & 0 & 21 & 60 & 14 & 40 & 100 \\
\hline Post-harvest process & 24 & 68.6 & 11 & 31.4 & 0 & 0 & 100 \\
\hline Capital ownership & 33 & 94.3 & 0 & 0 & 2 & 5.7 & 100 \\
\hline Market information & 26 & 74.3 & 9 & 25.7 & 0 & 0 & 100 \\
\hline Networking & 33 & 94.3 & 2 & 5.7 & 0 & 0 & 100 \\
\hline
\end{tabular}


information, and strength of the network causing farmers/communities to occupy a very weak power in bargaining position in transactions with collectors. One party's existence with a better position than other parties led to patron-clients institutional in the dammar trading system (Kartikawati, 2014). In the patron-client relationship, the patron has more authority in each decision making than the client. The patron-client relationship between the farmers and middle-men is done in a long period, and it may contain both positive and negative sides. Patron maintains the relationship to secure the supply; meanwhile, the client also can get certainty and assure their business sustainability (Sudrajat \& Arani, 2016). Clients in the dammar trading often get loans (credits) to fulfill farming input or other household needs, flexibility on the loan repayment period, protection when facing difficulties, personal support, and improved access to some resources and information. The patron-client system is determined by how much the client relied on their patron and how it is followed by social capital and balance in the mastery of information. Based on Febrianto \& Rahardjo (2005), the patron tends to have exploitative behavior such as blocking the client to access the market, so the clients always relied on the patron. In most cases, the patron allegedly gets more benefit than the client.

Dammar gum marketing channels There are several marketing channels with many actors involved, which can be described in dammar market. The actors involved in the dammar market are farmers, collectors in repong, village collectors, district collectors, and big traders and exporters.
Based on the study results, there are three channels of the dammar market in Pesisir Barat Lampung (Figure 1).

The difference between those three marketing channels is the actors involved, the process, functions, and margins obtained by each actor, and some consideration that underlie actors to choose a specific channel. Trading channel 1 is the most common in the exploitation of dammar gum in Pekon Pahmungan. Up to $80 \%$ of respondents choose to sell the harvested dammar gum through this channel. Some considerations that underlie farmers to choose this channel include: 1) yields are not abundant, 2) consideration of greater profits compared to selling dammar gum through the channel 2. 3) farmers do not carry out post-harvest processes, and 4) there is a kinship, getting to know each other, and a history of cooperation with village collectors so that it creates an element of trust. According to Haris et al. (2000), the basis of a transaction is an informal agreement on the principle of mutual trust (informally trust-building transactions).

Trading channel 2 is different from trading channel 1 . The difference between this channel and trading channel 1 is the presence of a 'collector in repong'. The collector in repong is a buyer who confronts the farmer in the garden to buy dammar gum in the repong. The distance between repong and village is quite far, so transactions with traders in the repong are considered more efficient by some farmers' respondents. Farmers who choose this channel also do not need to find and sell their harvested dammar to village traders. If farmers need money in a relatively short time, they tend to sell their dammar gum to traders in the garden. This channel's weaknesses are: 1) makes farmers become more passive

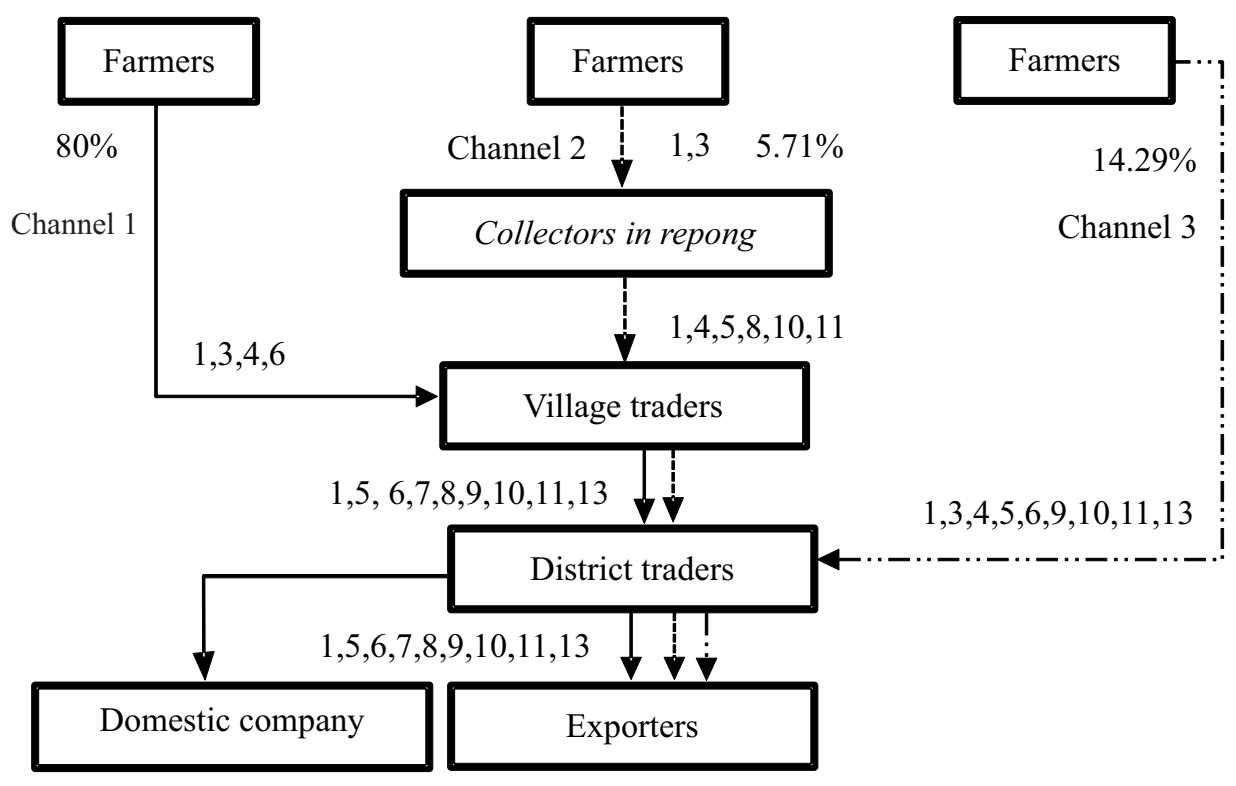

Note: $1=$ Sales, $2=$ Purchasing, $3=$ Harvesting, $4=$ Transportation, $5=$ Storage, $6=$ Packaging, $7=$ Transportation, $8=$ Loading and unloading, $9=$ Labor, $10=$ Sorting, $11=$ Depreciation, $12=$ Processing, $13=$ Market information

Figure 1 Marketing channel of dammar gum trading system in Pesisir Barat Lampung. 
actors in determining the selling price and make them weaker in bargaining position, and 2) makes dammar gum theft increasingly widespread.

In trading system channel 3, farmers bring their crops directly to big traders. Farmers in this channel carry out equivalent functions such as village collectors, which are characterized by activities: storage, packaging, laboring, sorting, shrinking, and market information. The main considerations of farmers in choosing this trading system channel are 1) large business scale, 2) having resources to conduct post-harvest activities, and 3) economic considerations, where this channel provides greater margins for farmers.

Different patterns of marketing channels cause a difference in level price and marketing margins received by each actor involved in the channel. According to Sudiyono (2002), the shorter the marketing chain especially, will make: (1) the cost of the trading system will be lower, (2) trading system margins also will be lower, (3) the price customer must be paid will be lower, and (4) price received by farmers (producers) will be higher. It appears that trading channel 3 gives more profit to the farmers than other trading channels.

Marketing margins and farmer's share analysis In the marketing of a product, it is also important to consider the products' marketing margin. The marketing margin can be defined as the difference between the producers' price for the raw product and the price the consumers pay for the final or semifinal product (Wohlgenant, 2001). The distribution of marketing margins between actors can be used as an approach that determines whether the market chain is efficient or not and provides a proportional benefit to producers and actors or not in accordance with the marketing costs, risks, and sacrifices that have been issued by each actor (Kartikawati, 2014). Margin distribution at each level of the institution in the dammar trading chain is presented in Table 2, and the recapitulation of dammar gum margins is presented in Table 3.

Table 3 indicates the margin distribution in the dammar gum trading system. Marketing efficiency is determined by various factors, such as the profit margin, marketing margin, and farmer's share. Most of the farmers (up to $85.71 \%$ of total) in Pekon Pahmungan use trading channels 1 and 2 to sell their harvested dammar. Meanwhile, based on the analysis of profit margin, it appears that farmers in channels 1 and 2 are trading actors that receive the lowest profit margin (IDR7,100 $\mathrm{kg}^{-1}$ and IDR8,100 $\mathrm{kg}^{-1}$ ) compared to trading channel 3 (IDR14,000 kg $\mathrm{kg}^{-1}$. This is due to farmers on channel 3 obtain another post-harvested process and spend more cost on it. Daniel (2002) stated that the greater the marketing margins, the more indicated the channel is more inefficient, and vice versa. As seen in those three channels, channel 3 is more efficient from other channels because farmers in channel 3 receive a bigger profit margin (IDR14,000 $\mathrm{kg}^{-1}$ ) and the lowest marketing margin (IDR7,550 kg-1). This also shows that short channels (channel 3) are more efficient than a long channel (channel 1 and 2).

The higher the farmer's share, the better the market performance from the producer (farmer) side. Farmer's share obtained by dammar farmers in this study was $55.30 \%$ in channel $1,52.20 \%$ in channel 2 , and $76.80 \%$ on channel 3 . Farmer's share can be increased so that the difference or margin between farmers and traders is not too large, as seen in the channel 3. From the three channels that occur in the dammar trade, the most efficient marketing channel is the channel three because it is the shortest marketing channel, has the smallest margin, and has the biggest farmer share $(76.80 \%)$ from other marketing channel patterns. With the assumption that producers are the most responsible party who has a big risk, so that farmers have the right to get an adequate proportion of returns, the greater the proportion of farmers' prices, the fairer the existing marketing system is. These conditions will stimulate farmers to continue producing and manage the repong damar. However, marketing is an essential subsystem, and it does not mean that the farmers, as the producers, don't need another marketing party. By increasing the farmer's share, doesn't mean eliminating the role of other marketing parties. There are some ways to increase farmer's share; by increasing product quality, diversifying products, and choosing more efficient trading channels.

The price of dammar gum on the farmer's side as producers is an indicator of local community interest in dammar gum business, especially for the local community/farmers who still depend entirely on dammar gum production. Based on the interview results, the price of dammar gum at the producer level in 5 years ago has reached IDR23,000 $\mathrm{kg}^{-1}$ to IDR25, $000 \mathrm{~kg}^{-1}$. At that particular period, the local community's enthusiasm towards dammar cultivation is quite high. The price of dammar gum, which continues to decline, will impact its conservation aspects. Suppose dammar production doesn't seem sufficient to meet daily needs. In that case, farmers/local people will turn to other commodities that are more economically profitable or even cut down dammar trees to sell their wood to the sawmill industry. The price that farmers receive for their agroforestry products also has great implications for agricultural development. Jensen (2007) stated that increased profitability for farmers might lead them to change their production scale and marketing decisions; they may farmland more intensively, sell in larger quantities, adopt new technologies, and move land out of nonagricultural use.

On the other hand, the low price at the farming community, the production revenue, and the cost can cause land conversion or switch crops. Hulu et al. (2017) stated that land conversion could be caused by low prices, price fluctuations, production income, and production costs on the farmer's side. Low farmer exchange rates mean that there is no incentive for farmers to continue to earn a living from the agroforestry business, so they tend to convert their plantations. Moreover, low productivity and various other socio-cultural problems also play an important role in land conversion. The root of the dammar gum crisis is low productivity, the absence of incentives and assistance from the government and educational institutions, and the dammar gum trading system's weak performance in recent years. The weak performance of the dammar gum trading system on the farmer's side is due to farmers' low knowledge about the post-harvest process, access to market information, capital ownership, and networking. 
Table 2 Margin distribution at every level of the institution in the trading chain of dammar

\begin{tabular}{|c|c|c|c|c|c|}
\hline & Variable & Unit & Unit price (IDR ) & Count ( IDR) & Price (IDR kg ${ }^{-1}$ ) \\
\hline 1 & Farmers/Local community & & & & \\
\hline $\mathrm{a}$ & Selling price & $150 \mathrm{~kg}$ & 18,000 & $2,700,000$ & 18,000 \\
\hline \multirow[t]{2}{*}{$\mathrm{b}$} & Cost & & & & \\
\hline & Accomodation & & & & \\
\hline & Cigarette & 25 days & 15,000 & 375,000 & 2,500 \\
\hline & Consumption & 25 days & 30,000 & 750,000 & 5,000 \\
\hline & Gasoline & 1 month & 100,000 & & 667 \\
\hline & Tools & & & & \\
\hline & Alit/ambong & 2 unit & 30,000 & 60,000 & 400 \\
\hline & Kapak & 2 unit & 50,000 & 100,000 & 667 \\
\hline & Bobalang & 2 unit & 50,000 & 100,000 & 667 \\
\hline & Total amount of cost & & & $1,740,000$ & 9,900 \\
\hline $\mathrm{c}$ & Profit margin & & & & 8,100 \\
\hline 2 & Collector in pekon & & & & \\
\hline \multirow[t]{2}{*}{ a } & Purchase price & & & & 17,000 \\
\hline & Selling price & & & & 18,000 \\
\hline \multirow[t]{5}{*}{ b } & Cost & & & & \\
\hline & Transportation & & $\mathrm{kg}^{-1}$ & & 250 \\
\hline & Packaging & & & & - \\
\hline & Marketing margin & & & & 1,000 \\
\hline & Profit margin & & & & 750 \\
\hline 3 & Village traders & & & & \\
\hline \multirow[t]{2}{*}{$\mathrm{a}$} & Purchase price & $340 \mathrm{~kg}$ & 18,000 & $6,120,000$ & 18,000 \\
\hline & Selling price & $340 \mathrm{~kg}$ & 25,000 & $8,500,000$ & 25,000 \\
\hline \multirow[t]{8}{*}{$\mathrm{b}$} & Cost & & & & \\
\hline & Packaging & & & & \\
\hline & Transportation & & $\mathrm{kg}^{-1}$ & & 200 \\
\hline & Loading unloading & & & & \\
\hline & Sorting & & $\mathrm{kg}^{-1}$ & & 150 \\
\hline & Retribution & & & & - \\
\hline & Storage & & & & - \\
\hline & Depreciation & & $\mathrm{kg}^{-1}$ & & 750 \\
\hline $\mathrm{c}$ & Marketing margin & & & & 7,000 \\
\hline $\mathrm{d}$ & Profit margin & & & & 5,900 \\
\hline 4 & District seller/exporters & & & & \\
\hline \multirow[t]{2}{*}{$\mathrm{a}$} & Purchase price & & & & 25,000 \\
\hline & Selling price & & & & 32,550 \\
\hline \multirow[t]{9}{*}{$\mathrm{b}$} & Cost & & & & \\
\hline & Packaging & & & & \\
\hline & Transportation from village traders & & $\mathrm{kg}^{-1}$ & & 200 \\
\hline & Loading unloading & & & & \\
\hline & Transports to consumers & & $\mathrm{kg}^{-1}$ & & 572 \\
\hline & Sorting & & $\mathrm{kg}^{-1}$ & & 150 \\
\hline & Retribution & & $\mathrm{kg}^{-1}$ & & 50 \\
\hline & Storage & & & & - \\
\hline & Depreciation & & $\mathrm{kg}^{-1}$ & & 20 \\
\hline $\mathrm{c}$ & Marketing margin & & & & 7,550 \\
\hline d & Profit margin & & & & 6,558 \\
\hline
\end{tabular}

Table 2 Margin distribution at every level of the institution in the trading chain of dammar

\begin{tabular}{|c|c|c|c|c|c|c|c|c|c|}
\hline \multirow{2}{*}{$\begin{array}{c}\text { Information } \\
\text { Channel } \\
\end{array}$} & \multicolumn{3}{|c|}{ Farmer (IDR kg ${ }^{-1}$ ) } & \multirow{2}{*}{$\begin{array}{l}\text { Collector } \\
\text { in repong } \\
\left(\mathrm{IDR} \mathrm{kg}^{-1}\right)\end{array}$} & \multirow{2}{*}{$\begin{array}{c}\text { Village } \\
\text { trader } \\
\left(\mathrm{IDR} \mathrm{kg}^{-1}\right)\end{array}$} & \multirow{2}{*}{ 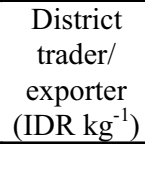 } & \multicolumn{3}{|c|}{ Farmer's share } \\
\hline & $\mathbf{I}$ & II & III & & & & $\mathbf{I}$ & II & III \\
\hline Price & 18,000 & 17,000 & 25,000 & 17,000 & 25,000 & 32,550 & & & \\
\hline Cost & 9,900 & 9,900 & 11,000 & 250 & 1100 & 992 & & & \\
\hline Marketing margin & 0 & 0 & 0 & 1,000 & 7,000 & 7,550 & 55,30 & 52,30 & 16,80 \\
\hline Profit margin & 8,100 & 7,100 & 14,000 & 750 & 5,900 & 6,558 & & & \\
\hline
\end{tabular}




\section{Conclusion}

There are three channels of the dammar market in Pesisir Barat Lampung. Most of the farmers (up to $85,71 \%$ of total) in Pekon Pahmungan use trading channels 1 and 2 to sell their harvested dammar. Meanwhile, based on the analysis of profit margin, it appears that farmers in channels 1 and 2 are trading actors that receive the lowest profit margin (IDR7,100 $\mathrm{kg}^{-1}$ and IDR8,100 $\mathrm{kg}^{-1}$ ) compared to trading channel 3 (IDR14,000 kg $\mathrm{kg}^{-1}$ ). Farmer's share obtained by dammar farmers in this study was $55.30 \%$ on channel 1 , $52.20 \%$ on channel 2 , and $76.80 \%$ on channel 3 . A strong external factor was not formed in the series of dammar gum trading activities in Pesisir Barat Lampung. The dammar gum crisis roots are low productivity, the absence of incentives and assistance from the government and educational institutions, plus the weak performance of the dammar gum trading system in recent years. The complex interplay of different drivers causes deforestation of repong damar, but the dammar gum's price as the main commodity of repong damar is a paramount factor. The market price of certain resources is influenced by its trading system (the farmers, the traders, and the interaction between actors in the market). The trading system's performance influences the relative prices, which affect farmers' motivation to conserve their land. The weak performance of dammar gum trading system in the farmer's side is due to the insufficient knowledge of farmers in the aspect of knowledge about the post-harvest process, access to market information, capital ownership, and networking. Because of these limitations, farmers' bargaining position is generally low in the transaction process, so that the trading system does not provide a large marketing margin for farmers. Farmers in this study are in a weaker bargaining position and remain as the price taker rather than a price maker; this is mainly related to small farmers' characteristics.

\section{Recommendation}

To enlarge the scale of their business and increase the selling volume and selling price product. It is suggested to the dammar farmers to improve the quality and productivity and choose the marketing channel that is more benefit able. To concrete this implication, we suggest the government give farmers some capital and empowerment programs to increase farmers'/communities' capacity in post-harvest processing, technological mastery, and access to information of dammar gum trading in Pesisir Barat Lampung. The government is also responsible for guiding, contributing, and counseling farmers to be more skillful and motivated in dammar gum farming. So they can increase their income and welfare sustainably so that the sustainability of repong damar left in Pesisir Barat can be guaranteed.

\section{References}

Abbas, A., \& Suhaeti, R. N. (2016). Pemanfaatan teknologi pascapanen untuk pengembangan agroindustri perdesaan di Indonesia. Forum Penelitian Agro Ekonomi, 34, 21-34. https://doi.org/10.21082/ fae.v34n1.2016.21-34

Anasis, M. A., \& Sari, M. Y. A. R. (2015). Perlindungan indikasi geografis terhadap damar mata kucing (Shorea javanica) sebagai upaya pelestarian hutan (studi di Kabupaten Pesisir Barat Propinsi Lampung). Jurnal Hukum IUS QUIA IUSTUM, 4, 566-593. https://doi.org/ 10.20885/iustum.vol22.iss4.art3

Anderson, E., \& Weitz, B. (1989). Determinants of continuity in conventional industrial channel dyads, Marketing Science, 8, 310-323. https://doi.org/10.1287/ mksc.8.4.310

Azwar, S. (2012). Penyusunan skala psikologi (ed. 2). Yogyakarta: Pustaka Pelajar.

Barbier, E. B., \& Schulz, C. E. (1997). Wildlife, biodiversity and trade. Environment and Development Economics, 2(2), 145-172. https://doi.org/10.1017/S1355770X9 7000144

Blenkhorn, D. L., \& MacKenzie, H. F. (1996). Interdependence in relationship marketing. AsiaAustralia Marketig Journal, 4, 25-30. https://doi.org/ 10.1016/S1320-1646(96)70266-6

Bouamrane, M. (1996). A season of gold-putting a value on harvests from Indonesia agroforest. Agroforestry Today, $8,8-11$.

[BPS] Badan Pusat Statistik. (2018). Kabupaten Pesisir Barat dalam angka 2018. Lampung: Badan Pusat Statistik Kabupaten Lampung Barat.

Bromley, D. W. (1992). The commons, common property, and environmental policy. Environmental and Resource Economics, 2, 1-17. https://doi.org/10.1007\%2FBF003 24686

Curtois P., \& Subervie J. (2015). Farmer bargaining power and market information services. American Journal of Agricultural Economics, 97, 953-977. https://doi.org/ 10.1093/ajae/aau051

Devaux, A., Torero, M., Donovan, J., \& Horton, D. (2016). Innovation for inclusive value-chain development: Successes and challenges. Washington DC: International Food Policy Research Institute.

Febrianto, P. T., \& Rahardjo (2005) . Eksploitasi hubungan pandega-juragan dalam moderenisasi perikanan tangkap di Desa Grajagan, Kecamatan Purwohardjo, Kabupaten Banyuwangi. Sosiosains, 18, 325-339.

Fischer, C. (2010). Does trade help or hinder the conservation of natural resources? Review of Environmental Economics and Policy, 4, 103-121. https://doi.org/10.1093/reep/rep023

Gilbert, D. E. (2017). The 'capitalist squeeze' and the rise and fall of Sumatra's Krui agroforests. Human Ecology, 45, 711-717.https://doi.org/10.1007/s10745-017-9932-3

Guest, G., Bounce, A., \& Johnson, L. (2006). How many interviews are enough? An experiment with data 
saturation and variability. Field Methods, 18, 59-82. https://doi.org/10.1177/1525822X05279903

Haris, U., Gonasryah, I., \& Anwar, A. (2000). Analisis faktorfaktor penentu kelembagaan tataniaga petani karet di sentra produksi karet rakyat di Sumatera Selatan. Ekonomi dan Keuangan Indonesia, 48, 83-106. Retrieved from https://www.lpem.org/repec/lpe/efijnl/ 200004

Hulu, H. L., Iswandi, R. M., \& Indarsyih, Y. (2017). Faktorfaktor yang mempengaruhi konversi lahan perkebunan cengkeh di Desa Tolong Kecamatan Lede Kabupaten Pulau Taliabu Provinsi Maluku Utara. Jurnal Ilmiah Agribisnis, 2, 24-28. https://doi.org/10.33772/jia.v2i1. 6692

Jensen, R. (2007). The digital provide: Information (technology), market performance, and welfare in the South Indian fisheries sector. The Quarterly Journal of Economics, 122, 879-924. https://doi.org/10.1162/qjec. 122.3.879

Kartikawati, S. M., Zuhud, E. A. M., Hikmat, A., \& Kartodiharjo, H. (2014). Analisis kinerja kelembagaan tata niaga pasak bumi (Eurycoma longifolia jack) yang berkelanjutan di Kabupaten Kubu Raya dan Kota Pontianak, Kalimantan Barat. Jurnal Penelitian Sosial dan Ekonomi Kehutanan, 11, 153-164. https://doi.org/ 10.20886/jpsek.2014.11.2.153-164

Karyono, O. K., Sumadiwangsa, S., \& Poernama, B. M. (1996). Suatu kajian tentang produksi dan ekonomi damar di Sumatera Barat. Jurnal Peneliian Hasil Hutan, 14, 355-365. https://doi.org/10.20886/jphh.1996. 14.9.355-365

Kusters, K., Perez, M. R., de Foresta, H., Dietz, T., RosTonen, M., Belcher, B., ..., \& Wollenberg, E. (2008). Will agroforestry vanish? The case of damar agroforest in Indonesia. Human Ecology, 36, 357-370. https://doi.org/ $10.1007 / \mathrm{s} 10745-008-9168-3$

Kuswardani, R. A., Isnaini, Siregar, R. S., \& Sembiring, S. (2017). The role of government in supporting the development of agriculture in North Sumatra. IOSR Journal, 10, 96-102. https://doi.org/10.9790/238010120196102

Mary, F., \& Michon, G. (1987). When agroforest drive back natural forest: A socio-economic analysis of riceagroforest in Sumatra. Agroforestry System, 5, 27-55. https://doi.org/10.1007/BF00046412

Menggala, S. (2018). Improving Cinnamomum burmannii Blume value chains for farmer livelihood in Kerinci, Indonesia. European Journal of Medicine and Natural Sciences, 2, 22-42. https://doi.org/10.26417/ejmn.v2i1

Michon, G., Mary, F., \& Bompard, J. (1987). Multistoried agroforestry garden system in West Sumatra, Indonesia. Agroforestry Systems, 4, 315-338. https://doi.org/

\subsection{7/BF00048106}

Mkhawani, K., Motadi, S. A., Mabapa, N. S., Mbhenyane, X. G., \& Blaauw, R. (2016). Effects of rising food prices on household food security on femaleheaded households in Runnymede Village, Mopani District, South Africa. South African Journal of Clinical Nutrition, 29, 69-74. https://doi.org/10.1080/ 16070658.2016.1216504

Murniati, Garrity, D. P., \& Gintings, A. Ng. (2001). The contribution of agroforestry systems to reducing farmers' dependence on the resources of adjacent national parks: a case study from Sumatra, Indonesia. Agroforestry Systems, 52, 171-184. https://doi.org/10.1023/A:10120 47602192

Mutuo, P. K., Cadisch, G., Albrecht, A., Palm, C. A., \& Verchot, L. (2005). Potential of agroforestry for carbon sequestration and mitigation of greenhouse gas emissions from soils in the tropics. Nutrient Cycling in Agroecosystems, 71, 43-54. https://doi.org/10.1007/s10 705-004-5285-6

Nyhus, P., \& Tilson, R. (2004). Agroforestry, elephants, and tigers: Balancing conservation theory and practice in human-dominated landscapes of Southeast Asia. Agriculture, Ecosystems and Environment, 104, 87-97. https://doi.org/10.1016/j.agee.2004.01.009

Puspitasari, A. W. (2015). Farmer's prosperity: How to increase farmer's bargain power (in Islamic perspective). Social and Behavioral Sciences, 211, 455-460. https://doi.org/10.1016/j.sbspro.2015.11.060

Ruhimat, I. S. (2017). Peningkatan kapasitas kelembagaan kelompok tani dalam pengembangan usahatani agroforestry: Studi kasus di Desa Cukangkawung, Kecamatan Sodonghilir, Kabupaten Tasikmalaya, Provinsi Jawa Barat. Jurnal Penelitian Sosial dan Ekonomi Kehutanan, 14, 1-17. https://doi.org/10.20886/ jpsek.2017.14.1.1-17

Sudiyono, A. (2002). Pemasaran pertanian. Malang: UMM Press.

Sudrajat, J., \& Arani, N. (2016). Institutional economic reconstruction by optimizing the role of middle-men. MIMBAR, 32, 65-73. https://doi.org/10.29313/mimbar. v32i1.1743

Triyono, P. (2000). Perkembangan posisi tawar petani dalam pemasaran damar mata kucing di Lampung. Jurnal Sosial Ekonomi, 1, 4961.

Wohlgenant, M.K. (2001). Marketing margins: Empirical analysis. Handbook of Agricultural Economics, 1, 933-970. https://doi.org/10.1016/S1574-0072(01)100 24-1

Wollenberg, E., Nawir, A., Uluk, A., \& Pramono, H. (2001). Income is not enough: The effect of economic incentives on forest product conservationA comparison of forest 
communities dependent on the agroforests of Krui, Sumatra, and natural dipterocarp forests of Kayan Mentarang, East Kalimantan. Bogor: Center for International Forestry Research (CIFOR)

Yustika, A. E. (2008). Ekonomi kelembagaan. Definisi, teori, dan strategi. Malang: Bayumedia Publishing.

Zuhud, E. A. M. (2007). Sikap masyarakat dan konservasi. Suatu analisis kedawung (Parkia timoriana (DC) Merr.) sebagai stimulus tumbuhan obat bagi masyarakat, kasus di Taman Nasional Meru Betiri [dissertation]. Bogor: Institut Pertanian Bogor. 